\title{
Detection and characterization of birch pollen in the atmosphere using a multiwavelength Raman polarization lidar and Hirst-type pollen sampler in Finland
}

\author{
Stephanie Bohlmann $^{1}$, Xiaoxia Shang ${ }^{1}$, Elina Giannakaki ${ }^{1,2}$, Maria Filioglou $^{1}$, Annika Saarto ${ }^{3}$, \\ Sami Romakkaniemi ${ }^{1}$, and Mika Komppula ${ }^{1}$ \\ ${ }^{1}$ Finnish Meteorological Institute, Atmospheric Research Centre of Eastern Finland, 70211 Kuopio, Finland \\ ${ }^{2}$ Department of Environmental Physics and Meteorology, University of Athens, 15784 Athens, Greece \\ ${ }^{3}$ Biodiversity Unit, University of Turku, 20014 Turku, Finland
}

Correspondence: Stephanie Bohlmann (stephanie.bohlmann@fmi.fi)

Received: 9 July 2019 - Discussion started: 22 July 2019

Revised: 14 October 2019 - Accepted: 29 October 2019 - Published: 2 December 2019

\begin{abstract}
We present the results of birch pollen characterization using lidar and in situ measurements based on a $11 \mathrm{~d}$ pollination period from 5 to 15 May 2016 at the European Aerosol Research Lidar Network (EARLINET) station in Vehmasmäki (Kuopio; $62^{\circ} 44^{\prime} \mathrm{N}, 27^{\circ} 33^{\prime}$ E), Finland. The ground-based multiwavelength Raman polarization lidar Polly ${ }^{\mathrm{XT}}$ performed continuous measurements at this rural forest site and has been combined with a Hirst-type volumetric air sampler, which measured the pollen type and concentration at roof level $(4 \mathrm{~m})$. The period was separated into two parts due to different atmospheric conditions and detected pollen types. During the first period, high concentrations of birch pollen were measured with a maximum $2 \mathrm{~h}$ average pollen concentration of 3700 grains $\mathrm{m}^{-3}$. Other pollen types represented less than $3 \%$ of the total pollen count. In observed pollen layers, the mean particle depolarization ratio at $532 \mathrm{~nm}$ was $10 \pm 6 \%$ during the intense birch pollination period. Mean lidar ratios were found to be $45 \pm 7$ and $55 \pm 16 \mathrm{sr}$ at 355 and $532 \mathrm{~nm}$, respectively. During the second period, birch pollen was still dominant, but a significant contribution of spruce pollen was observed as well. Spruce pollen grains are highly nonspherical, leading to a larger mean depolarization ratio of $26 \pm 7 \%$ for the birch-spruce pollen mixture. Furthermore, higher lidar ratios were observed during this period with mean values of $60 \pm 3$ and $62 \pm 10 \mathrm{sr}$ at 355 and $532 \mathrm{~nm}$, respectively. The presented study shows the potential of the particle depolarization ratio to track pollen grains in the atmosphere.
\end{abstract}

\section{Introduction}

Atmospheric pollen is a well-known health threat as it can irritate the respiratory system and cause asthmatic symptoms (Bousquet et al., 2008). The number of people suffering from pollen-triggered diseases is rising (Schmidt, 2016), and the prevalence of pollen allergies is likely to further increase due to climate change as the pollination season becomes longer and pollen production increases (Lake et al., 2018). In addition to the well-known allergenic impacts, pollen also affects the climate (IPCC, 2013; WHO, 2003). Steiner et al. (2015) suggested that fragments of pollen act as cloud condensation nuclei $(\mathrm{CCN})$ and therefore influence cloud optical properties. Pollen can furthermore change ice cloud formation processes by acting as ice nuclei (IN) (von Blohn et al., 2005; Diehl et al., 2001, 2002).

Worldwide, 879 active stations have continuously monitored pollen type and concentration near ground level in 2016 (Buters et al., 2018). The majority of these stations operate with Hirst-type volumetric air samplers. These traditional pollen traps are operated manually, which requires human resources and is time consuming. In recent years, novel techniques have been developed to enable automated pollen monitoring and reduce workload. Those techniques use, for example, automated image recognition (Oteros et al., 2015) or fluorescence spectra (Crouzy et al., 2016; Richardson et al., 2019; Saito et al., 2018) to identify pollen types, and they could enable a systematic pollen monitoring at ground level in near-real-time. Systematic information on the vertical dis- 
tribution, however, is missing. Models are using phenological and meteorological data to forecast concentration and dispersion of pollen in the atmosphere. But observations, especially in the vertical direction, to evaluate the model results are rare or missing. Light detection and ranging (lidar) is an effective method to investigate the vertical distribution of aerosols, as it enables measurements with high vertical and temporal resolutions under ambient conditions. Recently, the signature of pollen grains has been observed in lidar measurements (Noh et al., 2013a, b; Sassen, 2008; Sicard et al., 2016). It has been revealed that nonspherical pollen generates strong laser depolarization, and thus information on particle shape can be retrieved. For example, Sassen (2008) measured a linear depolarization ratio at $694 \mathrm{~nm}$ up to $30 \%$ for paper birch in Alaska. In controlled laboratory experiments, Cao et al. (2010) measured the linear depolarization ratio of different pollen types and determined a linear depolarization ratio at $532 \mathrm{~nm}$ for paper birch of $33 \%$. In the absence of other depolarizing particles, the depolarization ratio could therefore be used to track pollen grains. Lidar-derived depolarization ratio profiles thus can provide information about the vertical distribution of pollen, which could result in an improvement in the model input parameters and serve as validation for model results.

Within our study, we aim to improve and deepen the knowledge of optical properties of pollen in the atmosphere by using a multiwavelength Raman polarization lidar. Finland provides suitable conditions for the observation of pollen as $78 \%$ of Finland's total area is forestland and sources of other highly depolarizing particles like dust are absent. Hence the contamination with other aerosols is considered to be small. During a 4-month measurement campaign in 2016, the multiwavelength Raman polarization lidar Polly ${ }^{\mathrm{XT}}$ (Engelmann et al., 2016) performed continuous measurements at the rural forest station in Vehmasmäki (Kuopio), which is part of the European Aerosol Research Lidar Network (EARLINET). Simultaneously, a Hirst-type volumetric air sampler was operated to obtain pollen type and concentration at roof level. Twenty-one different pollen types were detected from May to August 2016. In this study, we focus on the description of birch pollen and the mixture of birch and spruce pollen as birch is one of the most allergenic pollen types and the most allergenic tree pollen in northern, central and eastern Europe (D'Amato et al., 2007).

\section{Measurement site and instrumentation}

Our measurement campaign took place from the beginning of May to the end of August 2016 at Vehmasmäki, Finland $\left(62^{\circ} 44^{\prime} \mathrm{N}, 27^{\circ} 33^{\prime} \mathrm{E}\right.$; $190 \mathrm{~m}$ a.s.l. $)$; a rural forest site $18 \mathrm{~km}$ from the city center of Kuopio, Eastern Finland. The measurement site was equipped with the multiwavelength Raman polarization lidar Polly ${ }^{\mathrm{XT}}$ (Sect. 2.1) and a Hirst-type pollen sampler (Sect. 2.2). With this setup it is possible to combine vertical profiles of the aerosol properties above the site and the pollen concentration on the ground. Due to the location of the site, far from major aerosol sources like dust or anthropogenic aerosol and mainly surrounded by forest, the atmosphere is relatively clean and suitable for pollen studies.

\subsection{Lidar: Polly $\mathrm{XT}$}

Lidar measurements were conducted with the multiwavelength Raman polarization lidar Polly ${ }^{\mathrm{XT}}$ (Althausen et al., 2009; Baars et al., 2016; Engelmann et al., 2016). PollyXT has three emission wavelengths $(355,532$ and $1064 \mathrm{~nm})$ and seven detection channels. In addition to the three emitted wavelengths, the backscattered signals at the inelastic Raman-shifted wavelengths (387, 407 and $607 \mathrm{~nm}$ ) and the cross-polarized signal at $532 \mathrm{~nm}$ are detected. During nighttime, extinction and backscatter coefficient profiles at 355 and $532 \mathrm{~nm}$ can be determined independently using the Raman method (Ansmann et al., 1992). During daytime, the Klett-Fernald method (Fernald, 1984; Klett, 1981) is applied using the elastic signals due to the low signal-to-noise ratio for the Raman channels. The signal at the $407 \mathrm{~nm}$ Ramanshifted wavelength is used to determine water vapor mixing ratio profiles during dark hours (Filioglou et al., 2017). The simultaneous measurement of the cross-polarized and total backscattered light at $532 \mathrm{~nm}$ enables the determination of the linear particle depolarization ratio (PDR; Freudenthaler et al., 2009), which allows for the characterization of particle shape (Sassen, 2005). The measurement of multiple wavelengths allows for the retrieval of Angström exponents $(\AA)$, which are related to the particle size. The ratio of extinction to backscatter coefficient is called lidar ratio (LR). It is considered an important criterion for particle characterization, as it depends on single scattering albedo and backscatter phase function and therefore on the size distribution and the chemical composition of the aerosol particle. The LR is therefore considered to be aerosol-type dependent.

The operated lidar system has an initial spatial resolution of $30 \mathrm{~m}$ and a temporal resolution of $30 \mathrm{~s}$. Due to the biaxial setup of emission and detection units, the height of complete overlap between the laser and the receiver field of view is reached at about 800-900 m (Engelmann et al., 2016). An overlap correction can be applied on the basis of a simple technique proposed by Wandinger and Ansmann (2002), which allows operators to extend profiles down to around $500 \mathrm{~m}$. In this study, the lower limit of reliable profiles of vertically smoothed and temporally averaged optical properties is at around $800 \mathrm{~m}$. Uncertainties in nighttime lidar products are mainly determined by signal noise and the correction of Rayleigh scattering. The overall relative errors of the lidar-derived optical properties retrieved with the Raman method are in the range of 5\%-10\% for backscatter coefficients and depolarization ratios and $10 \%-20 \%$ for extinction coefficients (Ansmann et al., 1992; Baars et al., 2012). These 
uncertainties propagate to the retrieved Ångström exponents and LRs.

Further details on the setup, principle and error propagation of Polly XT can be found in Althausen et al. (2009) and Engelmann et al. (2016). Near-real-time measurements and Polly $\mathrm{XT}$ data can be accessed at the PollyNET website (http://polly.tropos.de/, last access: 22 November 2019).

\subsection{Pollen collector: Hirst-type volumetric air sampler}

A Hirst-type volumetric air sampler located next to the lidar, $4 \mathrm{~m}$ above ground, monitored the pollen concentration and type. This type of spore sampler enables continuous $7 \mathrm{~d}$ collection of pollen grains with $2 \mathrm{~h}$ time resolution. The sampling principle is based on the design described by Hirst (1952). With a flow rate of $10 \mathrm{~L} \mathrm{~min}^{-1}$, air is drawn into the sampling device through a $14 \mathrm{~mm} \times 2 \mathrm{~mm}$ orifice. A large wind vane on a rotatable sampler head makes the sampler sensitive to changes in wind direction and ensures that the orifice is always oriented towards the wind. Particles impact on an adhesive-coated plastic tape beneath the orifice. For this study, the tape, fixed on a rotating drum, was changed every $7 \mathrm{~d}$ and the pollen grains impacted on the tape were further analyzed under the microscope. The pollen type was determined using characteristic features of the examined pollen grains. By converting the counted spores on the sample tape surface in relation to the inlet air flow, the pollen concentration was obtained.

\section{Methodology}

Figure 1 shows the temporal variation in the pollen concentration (Fig. 1a), the range-corrected signal at $1064 \mathrm{~nm}$ (Fig. 1b) and the volume depolarization ratio at $532 \mathrm{~nm}$ (Fig. 1c) during the period 5-15 May 2016. This period represents the main birch pollination season of 2016 as $83 \%$ of the annual birch pollen had been collected during that time. A relatively large aerosol load was observed within the planetary boundary layer up to $\sim 3.5 \mathrm{~km}$. As shown in Fig. $1 \mathrm{c}$, the volume depolarization ratio ranges between $4 \%$ and $10 \%$ suggesting the presence of nonspherical particles. A detailed examination of the air masses arriving during this period along with modeled dust load using the BSCDREAM8b model (Basart et al., 2012) confirms the absence of dust in middle and northern Europe. Additionally, MODIS data (MODIS, 2019) were synergistically used to exclude smoke aerosol layers from biomass burning. Hence, the highly depolarizing aerosol layers were likely attributed to pollen, keeping in mind that some contamination with local anthropogenic aerosol is always possible.

Ground-level pollen concentration values presented in Fig. 1a were used to verify the strong pollination event in the beginning of May, which provides $50 \%$ of the annual birch pollen concentration. The event started in the evening (17:00 UTC) of 5 May and lasted until noon on 9 May (hereafter called period 1). During period 1 , the $2 \mathrm{~h}$

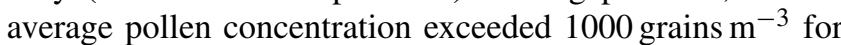
$53 \%$ of the time. The majority of pollen identified was birch $(97 \%)$ with a very small contribution from willow ( $2 \%)$ and other pollen types (1\%). From 12 to 15 May (period 2), the mean pollen concentration was significantly lower. Only $8 \%$ of the time, the total pollen concentration was higher than 1000 grains $\mathrm{m}^{-3}$. In addition to birch $(82 \%)$, spruce pollen $(14 \%)$ and other pollen types $(4 \%)$ were detected. This variation can be explained by the different meteorological conditions during the two periods. A different predominant wind direction during the two periods was observed, which probably caused the different mixtures of pollen types. The most frequent wind direction in period 1 was northwest, whereas in period 2 the air masses were mainly advected from the southeast. When comparing the diurnal cycle of temperature and relative humidity measured at ground level, we found higher temperature values and lower relative humidity during period 1 compared with period 2 . Temperature and pollen concentration have been shown to be positively correlated, whereas pollen concentration and relative humidity show a negative correlation (Bartková-Ščevková, 2003). The different pollen concentrations could therefore be partly explained by variations in temperature and humidity.

The near-ground aerosol layers are assumed to contain the highest concentration of local pollen, and they are defined as pollen layers in this study. The gradient method was applied to determine the bottom and top layer heights of the pollen layers (Bösenberg and Matthias, 2003; Flamant et al., 1997; Mattis et al., 2008). The local maximum in the first derivative of the $1064 \mathrm{~nm}$ backscatter coefficient was considered to be the bottom of the layer. The local minimum was considered to be the layer top. To verify the determined layers, the layer boundaries identified by the gradient method were compared with the bottom and top heights of coherent structures in the height-time illustration of the range-corrected signal (Giannakaki et al., 2015). The layer identification was based on the assumption that the optical properties should be relatively homogeneous, which means that within one layer the variability of the optical properties should be lower than the statistical uncertainty of the individual data points. Two layers with a vertical distance less than $100 \mathrm{~m}$ apart from each other were combined into one layer. All layers detected during the $11 \mathrm{~d}$ period are shown in Fig. 2. Black, magenta, blue and yellow bars show the first, second, third and fourth layers, respectively. Triangles mark the part of the layer which was used for calculations of the mean optical properties of the layer. The lower limit for reliable profiles during our measurement period was at around $800 \mathrm{~m}$. Since the closest layer to the ground is assumed to contain the highest pollen concentration and share, we only consider the lowest layers (black) in the following analysis. 

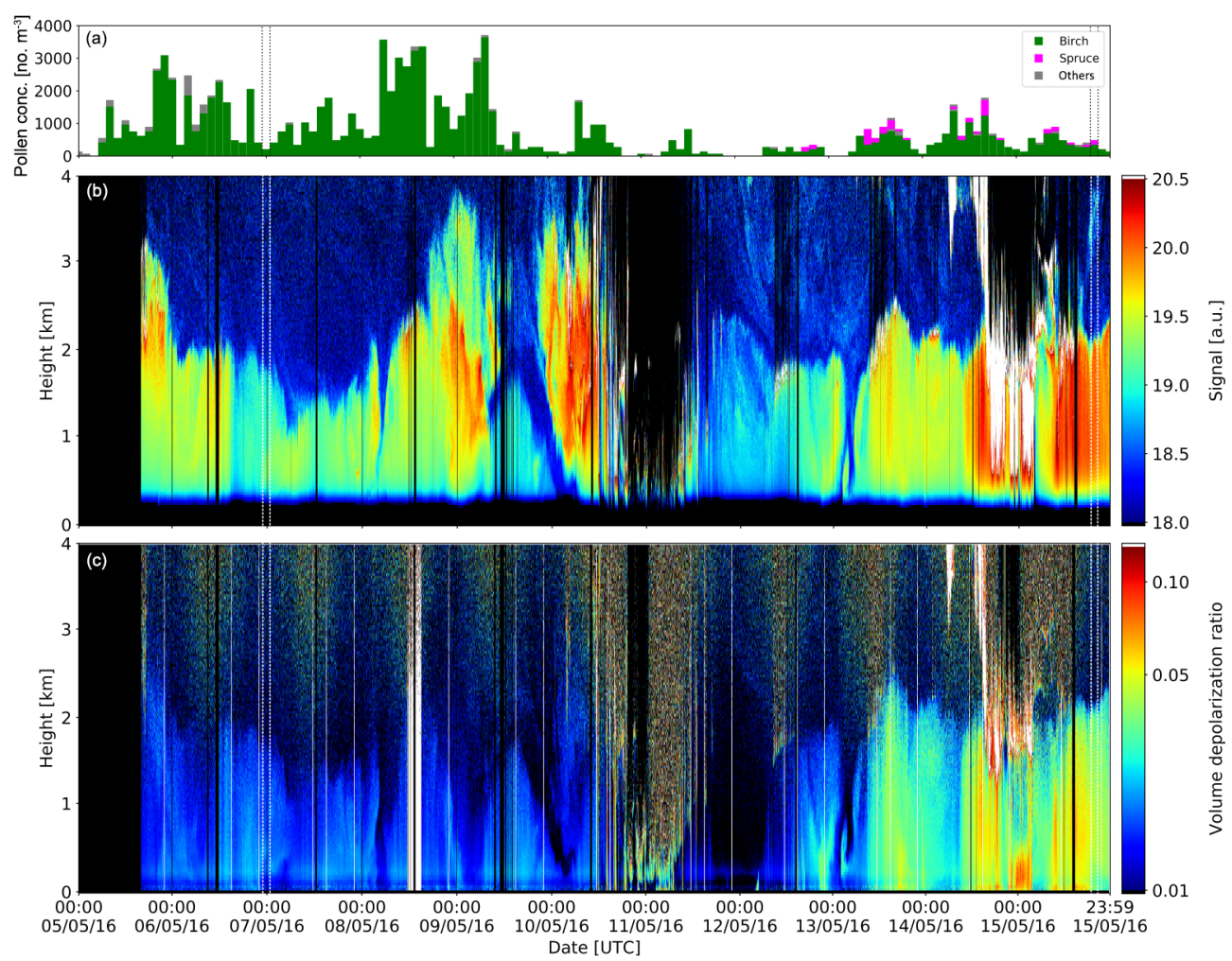

Figure 1. Overview of the $11 \mathrm{~d}$ birch pollen period. (a) Pollen concentration obtained from the Hirst-type pollen sampler, (b) range-corrected signal at $1064 \mathrm{~nm}$ and (c) volume depolarization ratio at $532 \mathrm{~nm}$. Dashed vertical lines mark the period of the case studies.

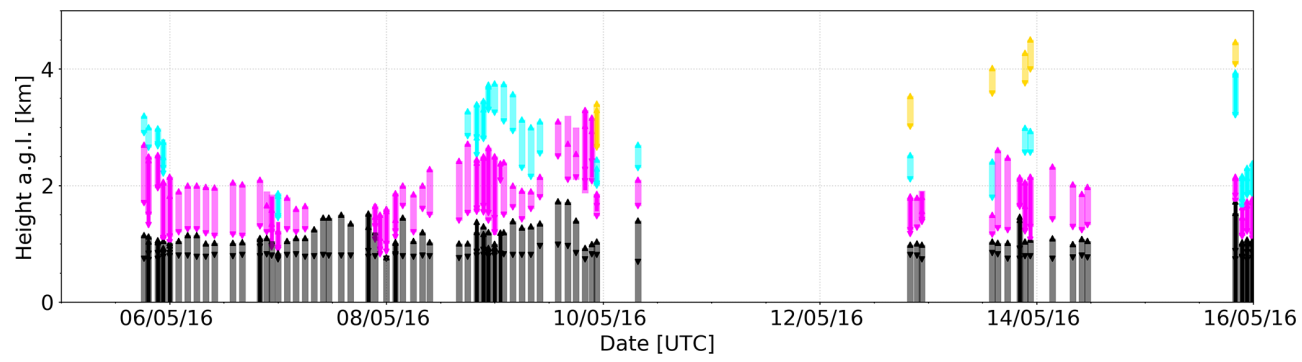

Figure 2. Layer definition during the measurement period 5-15 May 2016. The definition of layers is explained in Sect. 3. Colors mark the upper layers, which were not used for further analysis. Triangles mark the lower and upper limits of the area used for calculation.

\section{Results and discussion}

\subsection{Case studies}

We present two case studies representative for different pollen mixtures: in the first case study only birch pollen had been detected by the Hirst-type sampler, and in the second case study spruce pollen was detected in addition to birch. In the choice of case studies, backward trajectories have been considered to select cases with minimal contamination with of other aerosol. Furthermore, nighttime Raman measurements were chosen to present all lidar-derived parameters including the retrieved LR profile. Figure 3 shows, from left to right, the particle backscatter coefficient at
355 (blue), 532 (green) and $1064 \mathrm{~nm}$ (red); the particle extinction coefficient at 355 (dashed blue) and $532 \mathrm{~nm}$ (dashed green); the LR at 355 (blue) and $532 \mathrm{~nm}$ (green); the PDR at $532 \mathrm{~nm}$ (light green); the Ångström exponents calculated both from the backscatter coefficient at $355-532 \mathrm{~nm}$ (blue) and $532-1064 \mathrm{~nm}$ (red) and from extinction coefficients at $355-532 \mathrm{~nm}$ (black); and the relative humidity from lidarderived water vapor profiles (black) and temperature profiles from a radiosonde launched at 18:00 UTC (orange). Lidarderived optical properties were vertically smoothed using a sliding average of 25 bins $(750 \mathrm{~m})$. Four-day backward trajectories ending at the height of the layers and the middle of the time period are shown as well. 

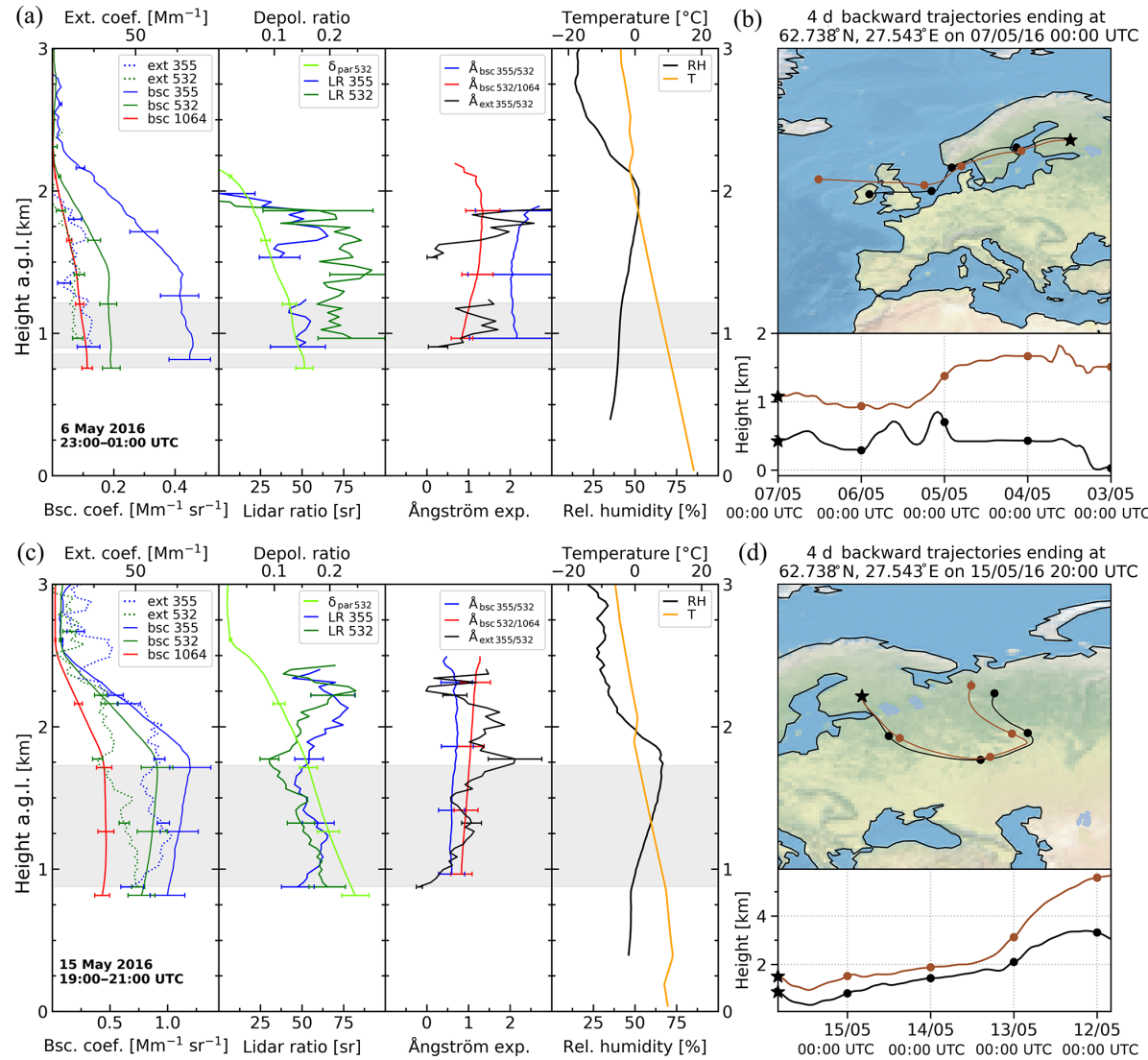

Figure 3. Two case studies of different pollen mixtures. (a, b) Period 1, 6 May 2016 23:00-01:00 UTC, only birch pollen was collected by the Hirst-type volumetric air sampler. (c, d) Period 2, 15 May 2016 19:00-21:00 UTC, birch and spruce pollen were collected. (a, c) Profiles of backscatter and extinction coefficients, particle depolarization and lidar ratio, Ångström exponents, relative humidity (derived from lidar measurements) and temperature profiles (18:00 UTC radio sounding). (b, d) Four-day HYSPLIT backward trajectories. Defined pollen layers are marked in gray.

The first case study was selected during the intense birch pollination event (period 1). On 6 May 2016 between 23:00 and 01:00 UTC only birch pollen was detected. Using the layer definition methodology (Sect. 3), three layers were determined, and the two lowest ones have been combined to one pollen layer for this analysis since the distance was less than $100 \mathrm{~m}$.

Four-day HYSPLIT (Hybrid Single Particle Lagrangian Integrated Trajectory) backward trajectories (Stein et al., 2015) ending at $450 \mathrm{~m}$ and $1.1 \mathrm{~km}$ on 7 May 00:00 UTC show that the air masses are advected from western directions and have traveled over the British Isles, the North Sea and southern Sweden. The contamination with depolarizing aerosol like dust is therefore considered to be negligible; however, the mixture with other anthropogenic aerosol cannot be ruled out. The presumed birch pollen layer was observed up to $1.2 \mathrm{~km}$. Extinction coefficient at $355 \mathrm{~nm}$ is about $22 \pm 2$ and is $13 \pm 1 \mathrm{Mm}^{-1}$ at $532 \mathrm{~nm}$. The mean LR for the observed layer is $49 \pm 4$ and $70 \pm 7 \mathrm{sr}$ at 355 and $532 \mathrm{~nm}$, respectively. Mean backscatter and extinction-related Ångström exponents at $355-532 \mathrm{~nm}$ are $2.1 \pm 0.04$ and $1.1 \pm 0.5$, respec- tively. The backscatter-related Ångström exponent between 532 and $1064 \mathrm{~nm}$ is $0.9 \pm 0.1$. The mean PDR at $532 \mathrm{~nm}$ within the layer is $14 \pm 1 \%$. Note that it can be even higher close to the ground, below the height of complete overlap. The PDR decreases with increasing height, while the LR remains constant. Thus the measured LR may not be a good indicator for characterizing the observed birch pollen in these cases as the contribution of pollen is assumed to decrease with increasing distance to the pollen source.

During our second case study on 15 May 2016 between 19:00 and 21:00 UTC, spruce pollen had been measured simultaneously with the birch pollen. Profiles and backward trajectories are shown in the lower row of Fig. 3 (Fig. 3c and d). The pollen layer reaches up to $1.7 \mathrm{~km}$.

The extinction coefficients at 355 and $532 \mathrm{~nm}$ are higher than in the previous case, being $61 \pm 5 \mathrm{Mm}^{-1}$ at $355 \mathrm{~nm}$ and $44 \pm 6 \mathrm{Mm}^{-1}$ at $532 \mathrm{~nm}$. The mean LR is $55 \pm 6 \mathrm{sr}$ at $355 \mathrm{~nm}$ and $51 \pm 9 \mathrm{sr}$ at $532 \mathrm{~nm}$. The backscatter and extinctionrelated Ångström exponents at $355-532 \mathrm{~nm}$ are lower than in the first case with values of 0.5 to 0.7 and 0.1 to 1.7 , 
(a)

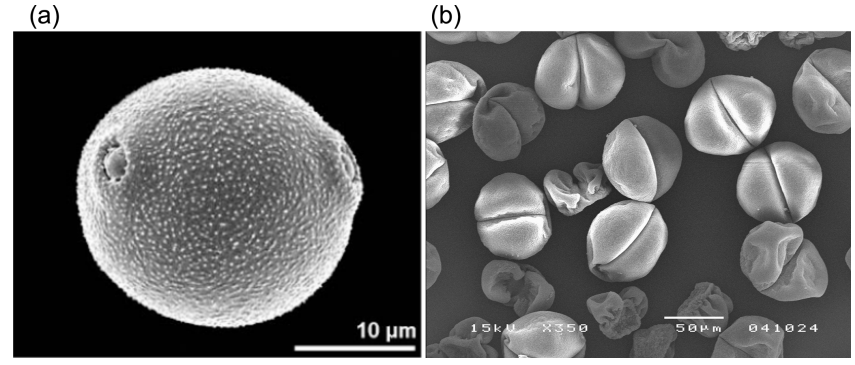

Figure 4. Pollen micrographs are shown. (a) Birch (Betula pendula) pollen grain (source: Halbritter and Diethart, 2016). (b) Spruce (Picea abies) pollen grains (source: the Biodiversity Unit of the University of Turku, Kari Kaunisto).

respectively. The backscatter-related Ångström exponent at $532-1064 \mathrm{~nm}$ is 0.8 to 1.0 .

The PDR at $532 \mathrm{~nm}$ is on average $19 \pm 2 \%, 24 \%$ at its maximum, and is clearly higher than in the case when only birch pollen was observed (period 1). The air masses arriving at the height of the layers on 15 May 20:00 UTC have been advected from Russia and remained close to the ground only for the last $12 \mathrm{~h}$ before reaching the site. The contamination with depolarizing dust can therefore be neglected. An explanation for the higher depolarization of the backscattered light is the nonspherical shape of the spruce pollen grains which have been detected in addition to birch pollen.

Figure 4 shows micrographs of birch and spruce pollen grains. Birch pollen (Fig. 4a) has a diameter around 20$30 \mu \mathrm{m}$, is almost spherical and possess three pores on the edge of the grain. Spruce pollen grains, on the other hand, possess two air bladders and are clearly nonspherical. Furthermore, those pollen grains are significantly larger, with their longest-axis diameter ranging between 90 and $110 \mu \mathrm{m}$ (including air bladders).

Pollen grains are low-density particles, which make them more sensitive to air currents, reduces the settling velocity and allows them to be lifted by turbulent air flows. Birch pollen, for example, has a gravitational settling velocity of around $1 \mathrm{~cm} \mathrm{~s}^{-1}$ (Sofiev et al., 2006). This settling velocity is similar to anthropogenic aerosol smaller than $10 \mu \mathrm{m}\left(\mathrm{PM}_{10}\right)$ although birch pollen grains are more than twice the size. The air bladders on the bigger spruce pollen grains increase the surface area of the grain without adding much mass and therefore decrease the settling velocity. Hence, even those big pollen grains can be lifted up to several kilometers and be dispersed by wind over thousands of kilometers as has been shown by several studies on the long-distance transport of pollen (Rousseau et al., 2008; Skjøth et al., 2007; Szczepanek et al., 2017).

\subsection{Lidar-derived optical parameters}

All pollen layers between 5 and 15 May have been identified and analyzed to determine the relationship between pollen type and the lidar-derived optical properties of the aerosol layer. Figure $5 \mathrm{a}$ shows the LR at $532 \mathrm{~nm}$ against the PDR at the same wavelength for all Raman measurements during nighttime. Measurements during the first intense birch pollination period are shown in green, while measurements during the second period, when spruce pollen was detected simultaneous to birch pollen, are shown in black. The size of the dots represents the measured pollen concentration by the Hirst-type sampler at ground level. The standard deviation is shown by the error bars. Lidar ratio values range from 31 to $74 \mathrm{sr}$. This wide range of LRs suggest that the LR alone is not a suitable parameter for the characterization of pollen as other aerosol types also show characteristic values in this range. However, the mean PDR within the pollen layers during the first period is $10 \pm 6 \%$, which is significantly higher than that of anthropogenic pollution. In the absence of other depolarizing aerosol, e.g., dust, pollen is likely the dominant aerosol causing this depolarization. Depolarization ratios higher than $15 \%$ are only observed during the second period (12-15 May) in which spruce pollen was present. The mean LR and PDR at $532 \mathrm{~nm}$ during this period are $62 \pm 10 \mathrm{sr}$ and $21 \pm 3 \%$, respectively. The significantly higher PDR is caused by the nonspherical shape of spruce pollen in those layers. In Fig. 5b, the backscatter-related Angström exponent between 532 and $1064 \mathrm{~nm}$ is shown against the PDR at $532 \mathrm{~nm}$ for all measurements between 5 and 15 May, including Klett retrievals for daytime measurements (dotted markers). A clear tendency towards smaller Ångström exponents with increasing depolarization ratios in both periods can be seen. This correlation indicates that the influence of nonspherical particles on the backscattered signal increases with decreasing Ångström exponent, i.e., bigger particles. The Ångström exponent in the second period is around 0.8 , whereas it is around 1 in the first period, demonstrating the effect of the larger spruce pollen $(\sim 90-110 \mu \mathrm{m})$, even with a small contribution $(\sim 14 \%)$ to the total pollen number concentration. But considering the different volumes of birch and spruce pollen grains, the contribution of spruce to the total volume concentration exceeds $75 \%$ in the second period, which may explain the large effect of spruce pollen on the measured optical properties even with a small number concentration.

However, the effect of the background particles has to be considered. Lidar measurements during the winter months of 2015 and 2016 and during pollen-free periods in spring and summer 2016 have been analyzed to determine the effect of background aerosol at our measurement site. During winter time the absence of pollen can be ensured but there is a possibility that pollen also had been present in the atmosphere during spring and summer when no pollen was detected by the Hirst-type sampler on the ground. Nevertheless, values of mean PDR at $532 \mathrm{~nm}$ are below $4 \%$ during all analyzed periods with no observed pollen. Since the PDR during the pollination period is significantly higher than the PDR of the background aerosol, the depolarization ratio can 


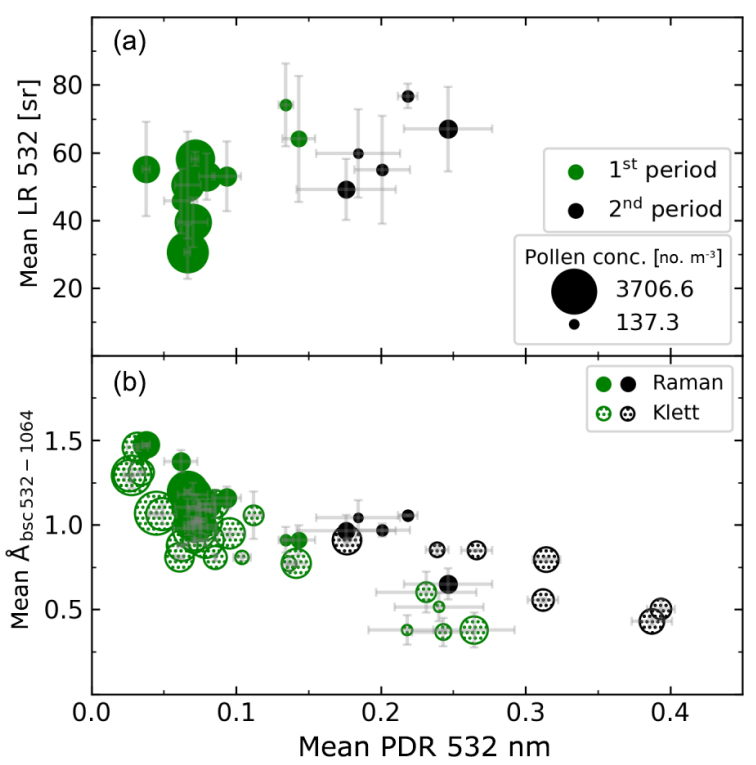

Figure 5. Mean values of optical properties of the detected pollen layers during the period 5 to 15 May. Error bars denote the standard deviation, and marker size denotes the pollen concentration. Marker color denotes the measurement period. Green dots are measured from 5 to 10 May and black dots from 12 to 15 May. Solid dots indicate Raman retrievals and dotted markers the Klett solution. Panel (a) shows lidar ratio at $532 \mathrm{~nm}$ vs. particle depolarization ratio at $532 \mathrm{~nm}$. Panel (b) shows backscatter-related Ångström exponent at 532-1064 nm vs. particle depolarization ratio at $532 \mathrm{~nm}$.

be used as an indicator for detecting the presence of pollen. The Ångström exponent, on the other hand, can be also related to the amount and type of background aerosol and is therefore less representative here.

Earlier studies show that relative humidity can affect the size and shape of pollen grains, which leads to different optical properties (Franchi et al., 1984; Griffiths et al., 2012; Katifori et al., 2010). When pollen grains dehydrate, the pollen wall can fold onto itself to prevent further dehydration, and this phenomena is known as harmomegathy (Katifori et al., 2010). The shape of the pollen grain changes, which could lead to significantly higher depolarization of the backscattered light. At humid conditions, pollen grains swell by taking up water internally and after reaching a relative humidity over $89 \%$ external wetting of the pollen surface can occur (Griffiths et al., 2012). To check whether the ambient relative humidity affects our measurements, the Ångström exponent $(532-1064 \mathrm{~nm})$ and the PDR at $532 \mathrm{~nm}$ are presented against the relative humidity in Fig. 6. In the selected measurement periods, the relative humidity ranged between $40 \%$ and $65 \%$. In this humidity range, Ångström exponent (Fig. 6a) and depolarization ratio (Fig. 6b) do not show any correlation with the relative humidity. Thus, our measurements were not affected by extreme humidity events and represent values for pollen under ambient atmospheric conditions in the spring season in Finland. However, lidar measurements of relative

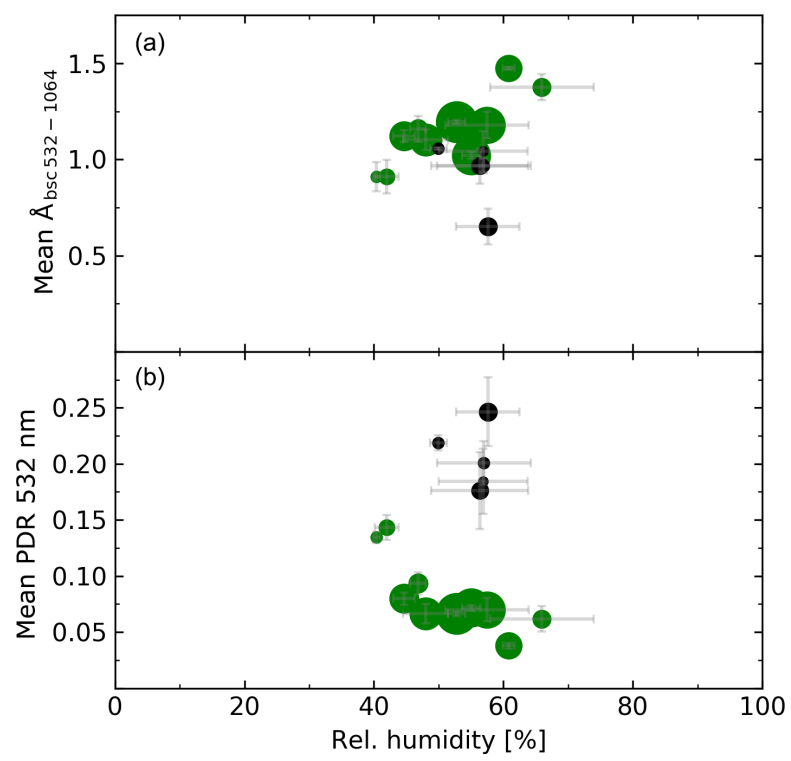

Figure 6. Dependence of the backscatter-related Ångström exponent at 532-1064 nm (a) and the particle depolarization ratio at $532 \mathrm{~nm}$ (b) on the relative humidity for all Raman measurements of pure and mixed birch cases during the first period (5-10 May, green) and the second period (12-15 May, black).

humidity profiles are only available during nighttime. The relative humidity in the observed pollen layers during daytime could be smaller. This could result in occasional folding of the pollen grains and higher depolarization ratios. This hypothesis could also explain the higher depolarization ratios of about $25 \%$ of a few Klett measurements of birch pollen during the first period.

Table 1 summarizes the mean intensive properties together with the associated standard derivation (SD), range and median in the first (birch) period of our campaign. The contribution of other pollen types in this period was small. Those values, therefore, can be considered to be characteristic for birch-pollen-dominated aerosol conditions. Table 2 shows the same properties for the spruce-contaminated period. Lidar ratio and PDR are higher when spruce is detected simultaneously with birch. The PDR values for birch pollen are considerably lower than previously determined in lidar studies. A linear depolarization ratio up to $30 \%$ at $694 \mathrm{~nm}$ was detected by Sassen (2008) for paper birch in Alaska. And under controlled laboratory environment, Cao et al. (2010) measured a linear depolarization ratio at $532 \mathrm{~nm}$ of $33 \%$ for dried paper birch pollen. We assume that those high depolarization values can be caused by dry birch pollen grains, which fold and change their shape when dehydrating. Under ambient conditions the pollen grains are more spherical and therefore less depolarizing. Also, the orientation of the pollen grains in the atmosphere has to be considered. Pollen with air bladders, e.g., spruce pollen, is known to align with its air bladders upwards when drifting in the air (Schwendemann 
Table 1. Mean values, range and median of optical properties of the detected pollen layers in the first measurement period: 5-10 May, intense birch pollination period.

\begin{tabular}{llrrr}
\hline \multicolumn{1}{c}{ Parameter } & & Mean $\pm \mathrm{SD}$ & Range & Median \\
\hline Layer top height $(\mathrm{km})$ & & $1.3 \pm 0.3$ & $1.0-2.2$ & 1.2 \\
\hline Backscatter coefficient & $355 \mathrm{~nm}$ & $0.7 \pm 0.5$ & $0.1-2.4$ & 0.7 \\
$\left(\mathrm{Mm}^{-1} \mathrm{sr}^{-1}\right)$ & $532 \mathrm{~nm}$ & $0.3 \pm 0.2$ & $0.1-1.0$ & 0.3 \\
& $1064 \mathrm{~nm}$ & $0.2 \pm 0.1$ & $0.1-0.4$ & 0.2 \\
\hline Extinction coefficient & $355 \mathrm{~nm}$ & $33.0 \pm 13.3$ & $20.0-68.2$ & 30.9 \\
$\left(\mathrm{Mm}^{-1}\right)$ & $532 \mathrm{~nm}$ & $19.0 \pm 6.5$ & $11.0-34.4$ & 19.1 \\
\hline Lidar ratio $(\mathrm{sr})$ & $355 \mathrm{~nm}$ & $46 \pm 8$ & $34-60$ & 46 \\
& $532 \mathrm{~nm}$ & $52 \pm 12$ & $31-74$ & 53 \\
\hline PDR & $532 \mathrm{~nm}$ & $0.10 \pm 0.06$ & $0.03-0.26$ & 0.08 \\
\hline Number of pollen layers & & all: 41 & Raman: 10 \\
\hline
\end{tabular}

Table 2. Mean values, range and median of optical properties of the detected pollen layers in the second measurement period: 12-15 May, spruce-contaminated period.

\begin{tabular}{llrrr}
\hline \multicolumn{1}{c}{ Parameter } & & Mean \pm SD & Range & Median \\
\hline Layer top height $(\mathrm{km})$ & & $1.3 \pm 0.4$ & $1-2.2$ & 1.1 \\
\hline Backscatter coefficient & $355 \mathrm{~nm}$ & $0.7 \pm 0.2$ & $0.3-1.1$ & 0.6 \\
$\left(\mathrm{Mm}^{-1} \mathrm{sr}^{-1}\right)$ & $532 \mathrm{~nm}$ & $0.5 \pm 0.2$ & $0.3-0.8$ & 0.4 \\
& $1064 \mathrm{~nm}$ & $0.3 \pm 0.1$ & $0.2-0.4$ & 0.2 \\
\hline Extinction coefficient & $355 \mathrm{~nm}$ & $52.9 \pm 13.1$ & $26.9-60.9$ & 58.5 \\
$\left(\mathrm{Mm}^{-1}\right)$ & $532 \mathrm{~nm}$ & $40.0 \pm 9.5$ & $24.6-54.6$ & 40.2 \\
\hline Lidar ratio $(\mathrm{sr})$ & $355 \mathrm{~nm}$ & $60 \pm 3$ & $55-64$ & 59 \\
& $532 \mathrm{~nm}$ & $62 \pm 10$ & $49-77$ & 60 \\
\hline PDR & $532 \mathrm{~nm}$ & $0.26 \pm 0.07$ & $0.18-0.39$ & 0.24 \\
\hline Number of pollen layers & & all: 12 & \multicolumn{2}{c}{ Raman: 5} \\
\hline
\end{tabular}

et al., 2007), and also an orientation of the almost spherical birch pollen grains was observed (Sassen, 2011; Tränkle and Mielke, 1994). This could cause differences in the measured optical properties if the orientation of the particles in laboratory experiments is not considered, or the irregularly shaped particles are observed from different angles.

\section{Conclusion}

Particle depolarization ratios of about $10 \%$ have been observed during a birch pollination event in Vehmasmäki, Finland. When more nonspherical pollen, e.g., spruce, is present, the particle depolarization ratio can be as high as $26 \%$. Those depolarization ratios are similar to dust and biomass-burning aerosol mixtures (Tesche et al., 2011) or dust mixtures with marine aerosol (Groß et al., 2011), thus pollen could easily be misclassified as dusty mixtures. The mean LRs show a wide range of values depending on the mixing of differ- ent pollen types in the atmosphere. The mean LR at $355 \mathrm{~nm}$ varies between $46 \pm 8 \mathrm{sr}$ (first period) and $60 \pm 3 \mathrm{sr}$ (second period) and at $532 \mathrm{~nm}$ between $52 \pm 12 \mathrm{sr}$ (first period) and $62 \pm 10 \mathrm{sr}$ (second period). Those LRs are characteristic for dust or dust-smoke mixtures (Tesche et al., 2011), which complicates the characterization of pollen using the LR. Also the backscatter-related Ångström exponents at 532$1064 \mathrm{~nm}$, which is around 1.0 for the intense birch pollination period and around 0.8 for the spruce-contaminated period, are similar to characteristic values for smoke and dustsmoke mixtures, respectively. Thus, in order to distinguish between pollen and other aerosol types, all three parameters and backward trajectories as well as possible dust and biomass-burning aerosol sources have to be considered.

The presented data show the potential of lidar measurements to detect pollen in the atmosphere. Nevertheless, there are challenges which need to be addressed in order to improve the characterization of optical properties of airborne 
pollen. First, the minimum height of the usable lidar signal needs to be as low as possible. By operating a lidar system with a low full-overlap height or additional near-field channels, the coverage of lower heights can be significantly improved. Second, the contribution of other aerosol types like anthropogenic pollution has to be determined. Therefore, more multiwavelength lidar studies with depolarization characterization on atmospheric pollen are necessary.

Data availability. Lidar data are available upon request from the authors and data "quicklooks" are available on the PollyNET website (http://polly.tropos.de/, last access: 22 November 2019). Trajectories are calculated with the NOAA (National Oceanic and Atmospheric Administration) HYSPLIT (HYbrid Single-Particle Lagrangian Integrated Trajectory) model (https://ready.arl.noaa.gov/ HYSPLIT.php, last access: 30 April 2019). Fire data are available at the NASA Worldview application (https://worldview.earthdata. nasa.gov, last access: 30 April 2019). BSC-DREAM8b model simulations are operated by the Barcelona Supercomputing Center and are available at https://ess.bsc.es/bsc-dust-daily-forecast/ (last access: 30 April 2019).

Author contributions. SB, XS and MF performed the lidar data analysis. AS analyzed the pollen samples. MK and EG initiated the measurement campaign. All authors contributed to the scientific discussion and the article preparation.

Competing interests. The authors declare that they have no conflict of interest.

Special issue statement. This article is part of the special issue "EARLINET aerosol profiling: contributions to atmospheric and climate research". It is not associated with a conference.

Acknowledgements. We acknowledge the use of data and imagery of BSC-DREAM8b simulations performed by the Barcelona Supercomputing Center and from the NASA Worldview application (https://worldview.earthdata.nasa.gov), part of the NASA Earth Observing System Data and Information System (EOSDIS). We thank the NOAA Air Resources Laboratory (ARL) for the provision of the HYSPLIT transport and dispersion model used in this publication.

Financial support. This project was supported by the Academy of Finland (project no. 310312).

Review statement. This paper was edited by Albert Ansmann and reviewed by two anonymous referees.

\section{References}

Althausen, D., Engelmann, R., Baars, H., Heese, B., Ansmann, A., Müller, D., and Komppula, M.: Portable Raman lidar Polly ${ }^{\mathrm{XT}}$ for automated profiling of aerosol backscatter, extinction, and depolarization, J. Atmos. Ocean. Tech., 26, 2366-2378, https://doi.org/10.1175/2009JTECHA1304.1, 2009.

Ansmann, A., Wandinger, U., Riebesell, M., Weitkamp, C., and Michaelis, W.: Independent measurement of extinction and backscatter profiles in cirrus clouds by using a combined Raman elastic-backscatter lidar, Appl. Opt., 31, 7113-7131, 1992.

Baars, H., Ansmann, A., Althausen, D., Engelmann, R., Heese, B., Müller, D., Artaxo, P., Paixao, M., Pauliquevis, T. and Souza, R.: Aerosol profiling with lidar in the Amazon Basin during the wet and dry season, J. Geophys. Res.-Atmos., 117, D21201, https://doi.org/10.1029/2012JD018338, 2012.

Baars, H., Kanitz, T., Engelmann, R., Althausen, D., Heese, B., Komppula, M., Preißler, J., Tesche, M., Ansmann, A., Wandinger, U., Lim, J.-H., Ahn, J. Y., Stachlewska, I. S., Amiridis, V., Marinou, E., Seifert, P., Hofer, J., Skupin, A., Schneider, F., Bohlmann, S., Foth, A., Bley, S., Pfüller, A., Giannakaki, E., Lihavainen, H., Viisanen, Y., Hooda, R. K., Pereira, S. N., Bortoli, D., Wagner, F., Mattis, I., Janicka, L., Markowicz, K. M., Achtert, P., Artaxo, P., Pauliquevis, T., Souza, R. A. F., Sharma, V. P., van Zyl, P. G., Beukes, J. P., Sun, J., Rohwer, E. G., Deng, R., Mamouri, R.-E., and Zamorano, F.: An overview of the first decade of PollyNET: an emerging network of automated Raman-polarization lidars for continuous aerosol profiling, Atmos. Chem. Phys., 16, 5111-5137, https://doi.org/10.5194/acp16-5111-2016, 2016.

Bartková-Ščevková, J.: The influence of temperature, relative humidity and rainfall on the occurrence of pollen allergens (Betula, Poaceae, Ambrosia artemisiifolia) in the atmosphere of Bratislava (Slovakia), Int. J. Biometeorol., 48, 1-5, https://doi.org/10.1007/s00484-003-0166-2, 2003.

Basart, S., Pérez, C., Nickovic, S., Cuevas, E., and Baldasano, J. M.: Development and evaluation of the BSCDREAM8b dust regional model over Northern Africa, the Mediterranean and the Middle East, Tellus B, 64, 18539, https://doi.org/10.3402/tellusb.v64i0.18539, 2012.

Bösenberg, J. and Matthias, V.: EARLINET: A European Aerosol Research Lidar Network to Establish an Aerosol Climatology, MPI Rep., 348, 6-31, 2003.

Bousquet, J., Khaltaev, N., Cruz, A. A., Denburg, J., Fokkens, W. J., Togias, A., Zuberbier, T., Baena-Cagnani, C. E., Canonica, G. W., Van Weel, C., Agache, I., Aït-Khaled, N., Bachert, C., Blaiss, M. S., Bonini, S., Boulet, L.-P., Bousquet, P.-J., Camargos, P., Carlsen, K.-H., Chen, Y., Custovic, A., Dahl, R., Demoly, P., Douagui, H., Durham, S. R., Van Wijk, R. G., Kalayci, O., Kaliner, M. A., Kim, Y.-Y., Kowalski, M. L., Kuna, P., Le, L. T. T., Lemiere, C., Li, J., Lockey, R. F., MavaleManuel, S., Meltzer, E. O., Mohammad, Y., Mullol, J., Naclerio, R., O’Hehir, R. E., Ohta, K., Ouedraogo, S., Palkonen, S., Papadopoulos, N., Passalacqua, G., Pawankar, R., Popov, T. A., Rabe, K. F., Rosado-Pinto, J., Scadding, G. K., Simons, F. E. R., Toskala, E., Valovirta, E., Van Cauwenberge, P., Wang, D.-Y., Wickman, M., Yawn, B. P., Yorgancioglu, A., Yusuf, O. M., Zar, H., Annesi-Maesano, I., Bateman, E. D., Kheder, A. Ben, Boakye, D. A., Bouchard, J., Burney, P., Busse, W. W., Chan-Yeung, M., Chavannes, N. H., Chuchalin, A., Dolen, 
W. K., Emuzyte, R., Grouse, L., Humbert, M., Jackson, C., Johnston, S. L., Keith, P. K., Kemp, J. P., Klossek, J.-M., Larenas-Linnemann, D., Lipworth, B., Malo, J.-L., Marshall, G. D., Naspitz, C., Nekam, K., Niggemann, B., NizankowskaMogilnicka, E., Okamoto, Y., Orru, M. P., Potter, P., Price, D., Stoloff, S. W., Vandenplas, O., Viegi, G., and Williams, D.: Allergic Rhinitis and its Impact on Asthma (ARIA) 2008, Allergy, 63, 8-160, https://doi.org/10.1111/j.1398-9995.2007.01620.x, 2008.

Buters, J. T. M., Antunes, C., Galveias, A., Bergmann, K. C., Thibaudon, M., Galán, C., Schmidt-Weber, C., and Oteros, J.: Pollen and spore monitoring in the world, Clin. Transl. Allergy, 8, 9, https://doi.org/10.1186/s13601-018-0197-8, 2018.

Cao, X., Roy, G., and Bernier, R.: Lidar polarization discrimination of bioaerosols, Opt. Eng., 49, 116201, https://doi.org/10.1117/1.3505877, 2010.

Crouzy, B., Stella, M., Konzelmann, T., Calpini, B., and Clot, B.: All-optical automatic pollen identification: Towards an operational system, Atmos. Environ., 140, 202-212, https://doi.org/10.1016/J.ATMOSENV.2016.05.062, 2016.

D’Amato, G., Cecchi, L., Bonini, S., Nunes, C., AnnesiMaesano, I., Behrendt, H., Liccardi, G., Popov, T., and van Cauwenberge, P.: Allergenic pollen and pollen allergy in Europe, Allergy, 62, 976-990, https://doi.org/10.1111/j.13989995.2007.01393.x, 2007.

Diehl, K., Quick, C., Matthias-Maser, S., Mitra, S. K., and Jaenicke, R.: The ice nucleating ability of pollen Part I: Laboratory studies in deposition and condensation freezing modes, Atmos. Res., 58, 75-87, https://doi.org/10.1016/S0169-8095(01)00091-6, 2001.

Diehl, K., Matthias-Maser, S., Jaenicke, R., and Mitra, S. K.: The ice nucleating ability of pollen: Part II. Laboratory studies in immersion and contact freezing modes, Atmos. Res., 61, 125-133, https://doi.org/10.1016/S0169-8095(01)00132-6, 2002.

Engelmann, R., Kanitz, T., Baars, H., Heese, B., Althausen, D., Skupin, A., Wandinger, U., Komppula, M., Stachlewska, I. S., Amiridis, V., Marinou, E., Mattis, I., Linné, H., and Ansmann, A.: The automated multiwavelength Raman polarization and water-vapor lidar Polly ${ }^{\mathrm{XT}}$ : the neXT generation, Atmos. Meas. Tech., 9, 1767-1784, https://doi.org/10.5194/amt-9-1767-2016, 2016.

Fernald, F. G.: Analysis of atmospheric lidar observations: some comments, Appl. Opt., 23, 652-653, 1984.

Filioglou, M., Nikandrova, A., Niemelä, S., Baars, H., Mielonen, T., Leskinen, A., Brus, D., Romakkaniemi, S., Giannakaki, E., and Komppula, M.: Profiling water vapor mixing ratios in Finland by means of a Raman lidar, a satellite and a model, Atmos. Meas. Tech., 10, 4303-4316, https://doi.org/10.5194/amt10-4303-2017, 2017.

Flamant, C., Pelon, J., Flamant, P. H., and Durand, P.: Lidar determination of the entrainment zone thickness at the top of the unstable marine atmospheric boundary layer, Bound.-Lay. Meteorol., 83, 247-284, https://doi.org/10.1023/A:1000258318944, 1997.

Franchi, G. G., Pacini, E., and Rottoli, P.: Pollen grain viability in Parietaria judaica L. during the long blooming period and correlation with meteorological conditions and allergic diseases, G. Bot. Ital., 118, 163-178, https://doi.org/10.1080/11263508409426670, 1984.

Freudenthaler, V., Esselborn, M., Wiegner, M., Heese, B., Tesche, M., Ansmann, A., Müller, D., Althausen, D., Wirth, M., Fix, A.,
Ehret, G., Knippertz, P., Toledano, C., Gasteiger, J., Garhammer, M., and Seefeldner, M.: Depolarization ratio profiling at several wavelengths in pure Saharan dust during SAMUM 2006, Tellus B, 61, 165-179, 2009.

Giannakaki, E., Pfüller, A., Korhonen, K., Mielonen, T., Laakso, L., Vakkari, V., Baars, H., Engelmann, R., Beukes, J. P., Van Zyl, P. G., Josipovic, M., Tiitta, P., Chiloane, K., Piketh, S., Lihavainen, H., Lehtinen, K. E. J., and Komppula, M.: One year of Raman lidar observations of free-tropospheric aerosol layers over South Africa, Atmos. Chem. Phys., 15, 5429-5442, https://doi.org/10.5194/acp-15-5429-2015, 2015.

Griffiths, P. T., Borlace, J.-S., Gallimore, P. J., Kalberer, M., Herzog, M., and Pope, F. D.: Hygroscopic growth and cloud activation of pollen: a laboratory and modelling study, Atmos. Sci. Lett., 13, 289-295, https://doi.org/10.1002/asl.397, 2012.

Groß, S., Tesche, M., Freudenthaler, V., Toledano, C., Wiegner, M., Ansmann, A., Althausen, D. and Seefeldner, M.: Characterization of Saharan dust, marine aerosols and mixtures of biomassburning aerosols and dust by means of multi-wavelength depolarization and Raman lidar measurements during SAMUM 2, Tellus B, 63, 706-724, https://doi.org/10.1111/j.16000889.2011.00556.x, 2011.

Halbritter, H. and Diethart, B.: Betula pendula, in: PalDat - A palynological database, available at: https://www.paldat.org/pub/ Betula_pendula/300732 (last access: 22 November 2019), 2016.

Hirst, J. M.: An automatic volumetric spore trap, Ann. Appl. Biol., 39, 257-265, https://doi.org/10.1111/j.17447348.1952.tb00904.x, 1952.

IPCC: Climate Change 2013: The Physical Science Basis. Contribution of Working Group I to the Fifth Assessment Report of the Intergovernmental Panel on Climate Change, edited by: Stocker, T. F., Qin, D., Plattner, G.-K., Tignor, M., Allen, S. K., Boschung, J., Nauels, A., Xia, Y., Bex, V., and Midgley, P. M., Cambridge University Press, 2013.

Katifori, E., Alben, S., Cerda, E., Nelson, D. R., and Dumais, J.: Foldable structures and the natural design of pollen grains, P. Natl. Acad. Sci. USA, 107, 7635-7639, https://doi.org/10.1073/pnas.0911223107, 2010.

Klett, J. D.: Stable analytical solution for processing lidar returns, Appl. Opt., 20, 211-220, 1981.

Lake, I. R., Jones, N. R., Agnew, M., Goodess, C. M., Giorgi, F., Hamaoui-Laguel, L., Semenov, M. A., Solmon, F., Storkey, J., Vautard, R., and Epstein, M. M.: Erratum: "Climate Change and Future Pollen Allergy in Europe,” Environ. Health Persp., 126, 079002, https://doi.org/10.1289/EHP2073, 2018.

Mattis, I., Müller, D., Ansmann, A., Wandinger, U., Preißler, J., Seifert, P., and Tesche, M.: Ten years of multiwavelength Raman lidar observations of free-tropospheric aerosol layers over central Europe: Geometrical properties and annual cycle, J. Geophys. Res., 113, D20202, https://doi.org/10.1029/2007JD009636, 2008.

MODIS: $\quad$ MODIS $\quad$ Collection 6 NRT Hotspot/Active Fire Detections MCD14DL, https://doi.org/10.5067/FIRMS/MODIS/MCD14DL.NRT.006, 2019.

Noh, M. Y., Müller, D., Lee, H., and Choi, T.: Influence of biogenic pollen on optical properties of atmospheric aerosols observed by lidar over Gwangju, South Korea, Atmos. Environ., 69, 139-147, https://doi.org/10.1016/j.atmosenv.2012.12.018, 2013a. 
Noh, Y. M., Lee, H., Mueller, D., Lee, K., Shin, D., Shin, S., Choi, T. J., Choi, Y. J., and Kim, K. R.: Investigation of the diurnal pattern of the vertical distribution of pollen in the lower troposphere using LIDAR, Atmos. Chem. Phys., 13, 7619-7629, https://doi.org/10.5194/acp-13-7619-2013, 2013b.

Oteros, J., Pusch, G., Weichenmeier, I., Heimann, U., Möller, R., Röseler, S., Traidl-Hoffmann, C., SchmidtWeber, C., and Buters, J. T. M.: Automatic and Online Pollen Monitoring, Int. Arch. A. Imm., 167, 158-166, https://doi.org/10.1159/000436968, 2015.

Richardson, S. C., Mytilinaios, M., Foskinis, R., Kyrou, C., Papayannis, A., Pyrri, I., Giannoutsou, E., and Adamakis, I. D. S.: Bioaerosol detection over Athens, Greece using the laser induced fluorescence technique, Sci. Total Environ., 696, 133906, https://doi.org/10.1016/j.scitotenv.2019.133906, 2019.

Rousseau, D.-D., Schevin, P., Ferrier, J., Jolly, D., Andreasen, T., Ascanius, S. E., Hendriksen, S.-E., and Poulsen, U.: Long-distance pollen transport from North America to Greenland in spring, J. Geophys. Res.-Biogeo., 113, G02013, https://doi.org/10.1029/2007JG000456, 2008.

Saito, Y., Ichihara, K., Morishita, K., Uchiyama, K., Kobayashi, F., and Tomida, T.: Remote Detection of the Fluorescence Spectrum of Natural Pollens Floating in the Atmosphere Using a LaserInduced-Fluorescence Spectrum (LIFS) Lidar, Remote Sens., 10, 1533, https://doi.org/10.3390/rs10101533, 2018.

Sassen, K.: Polarization in lidar, in Lidar: Range-Resolved Optical Remote Sensing of the Atmosphere, edited by: Weitkamp, C., Springer, 19-42, 2005.

Sassen, K.: Boreal tree pollen sensed by polarization lidar: Depolarizing biogenic chaff, Geophys. Res. Lett., 35, L18810, https://doi.org/10.1029/2008GL035085, 2008.

Sassen, K.: Elliptical pollen corona from North American boreal paper birch trees (Betula papyrifera): strong fall orientations for near-spherical particles, Appl. Opt., 50, F1-F5, https://doi.org/10.1364/AO.50.0000F1, 2011.

Schmidt, C. W.: Pollen Overload: Seasonal Allergies in a Changing Climate, Environ. Health Persp., 124, A70-A75, https://doi.org/10.1289/ehp.124-A70, 2016.

Schwendemann, A. B., Wang, G., Mertz, M. L., McWilliams, R. T., Thatcher, S. L., and Osborn, J. M.: Aerodynamics of saccate pollen and its implications for wind pollination, Am. J. Bot., 94, 1371-1381, https://doi.org/10.3732/ajb.94.8.1371, 2007.

Sicard, M., Izquierdo, R., Alarcón, M., Belmonte, J., Comerón, A., and Baldasano, J. M.: Near-surface and columnar measurements with a micro pulse lidar of atmospheric pollen in Barcelona, Spain, Atmos. Chem. Phys., 16, 6805-6821, https://doi.org/10.5194/acp-16-6805-2016, 2016.
Skjøth, C. A., Sommer, J., Stach, A., Smith, M. and Brandt, J.: The long-range transport of birch (Betula) pollen from Poland and Germany causes significant pre-season concentrations in Denmark, Clin. Exp. Allergy, 37, 1204-1212, https://doi.org/10.1111/j.1365-2222.2007.02771.x, 2007.

Sofiev, M., Siljamo, P., Ranta, H., and Rantio-Lehtimäki, A.: Towards numerical forecasting of long-range air transport of birch pollen: theoretical considerations and a feasibility study, Int. J. Biometeorol., 50, 392-402, https://doi.org/10.1007/s00484-0060027-x, 2006.

Stein, A. F., Draxler, R. R., Rolph, G. D., Stunder, B. J. B., and Cohen, M. D.: NOAA's HYSPLIT Atmospheric Transport and Dispersion Modeling System, B. Am. Meteorol. Soc., 96, 20592077, https://doi.org/10.1175/BAMS-D-14-00110.1, 2015.

Steiner, A. L., Brooks, S. D., Deng, C., Thornton, D. C. O., Pendleton, M. W., and Bryant, V.: Pollen as atmospheric cloud condensation nuclei, Geophys. Res. Lett., 42, 3596-3602, https://doi.org/10.1002/2015GL064060, 2015.

Szczepanek, K., Myszkowska, D., Worobiec, E., Piotrowicz, K., Ziemianin, M., and Bielec-Ba̧kakowska, Z.: The longrange transport of Pinaceae pollen: an example in Kraków (southern Poland), Aerobiologia (Bologna), 33, 109-125, https://doi.org/10.1007/s10453-016-9454-2, 2017.

Tesche, M., Groß, S., Ansmann, A., Müller, D., Althausen, D., Freudenthaler, V. and Esselborn, M.: Profiling of Saharan dust and biomass-burning smoke with multiwavelength polarization Raman lidar at Cape Verde, Tellus B, 63, 649-676, 2011.

Tränkle, E. and Mielke, B.: Simulation and analysis of pollen coronas, Appl. Opt., 33, 4552-4562, https://doi.org/10.1364/AO.33.004552, 1994.

von Blohn, N., Mitra, S. K., Diehl, K., and Borrmann, S.: The ice nucleating ability of pollen: Part III: New laboratory studies in immersion and contact freezing modes including more pollen types, Atmos. Res., 78, 182-189, https://doi.org/10.1016/j.atmosres.2005.03.008, 2005.

Wandinger, U. and Ansmann, A.: Experimental determination of the lidar overlap profile with Raman lidar, Appl. Opt., 41, 511-514, 2002.

WHO: World Health Report 2003: A Vision for Global Health, Shaping the Future, World Heal. Organ., 2003. 